Article

\title{
Variations of Soil Physico-Chemical and Biological Features after Logging Using Two Different Ground-Based Extraction Methods in a Beech High Forest-A Case Study
}

\author{
Rachele Venanzi $^{1}$, Francesco Latterini ${ }^{2, * \mathbb{D}}$, Walter Stefanoni ${ }^{2} \mathbb{D}$, Damiano Tocci ${ }^{1}$ and Rodolfo Picchio $^{{ }^{1} \mathbb{D}}$ \\ 1 Department of Agricultural and Forest Sciences, University of Tuscia, Via San Camillo de Lellis, \\ 01100 Viterbo, Italy; venanzi@unitus.it (R.V.); tocci@unitus.it (D.T.); r.picchio@unitus.it (R.P.) \\ 2 Consiglio per la Ricerca in Agricoltura e l'Analisi dell'Economia Agraria (CREA), \\ Centro di Ricerca Ingegneria e Trasformazioni Agroalimentari, Via della Pascolare 16, \\ 00015 Monterotondo, Italy; walter.stefanoni@crea.gov.it \\ * Correspondence: francesco.latterini@crea.gov.it
}

check for updates

Citation: Venanzi, R.; Latterini, F.; Stefanoni, W.; Tocci, D.; Picchio, R. Variations of Soil Physico-Chemical and Biological Features after Logging Using Two Different Ground-Based Extraction Methods in a Beech High Forest-A Case Study. Land 2022, 11, 388. https://doi.org/10.3390/ land 11030388

Academic Editor: Cezary Kabala

Received: 15 February 2022

Accepted: 4 March 2022

Published: 5 March 2022

Publisher's Note: MDPI stays neutral with regard to jurisdictional claims in published maps and institutional affiliations.

Copyright: (c) 2022 by the authors. Licensee MDPI, Basel, Switzerland. This article is an open access article distributed under the terms and conditions of the Creative Commons Attribution (CC BY) license (https:// creativecommons.org/licenses/by/ $4.0 /)$.

\begin{abstract}
Considering that forests are crucial in the ecosystem of our planet and that forests provide timber products as well as several ecosystem services, it is evident that the application of sustainable forest operations (SFOs) is of substantial importance to achieve sustainable forest management (SFM). One of the most important issues to be evaluated when dealing with SFOs is limiting the disturbance and impacts related to logging. Harvesting activities can indeed alter the conditions of soil through compaction and litter removal which can also lead to modifications from the biological point of view, for example, diminishing the presence of soil microarthropods. While keeping these objectives in focus, the aim of the present study was to evaluate physico-chemical and biological impacts on forest soil in Mediterranean beech forests after forest logging with two different extraction systems, which are forestry-fitted farm tractors equipped with winch and forwarder. Specifically, authors aimed to investigate: (i) soil disturbance levels of ground-based extraction methods; (ii) soil disturbance levels of the applied forestry intervention; (iii) soil disturbance levels between winchingskidding and forwarding. Findings showed that the physical, chemical, and biological soil features were slightly disturbed by the forestry itself. In addition, forest operations and machine traffic showed clear soil disturbance, resulting in a substantial alteration of the characteristics. Between the two extraction techniques tested, winching caused less disturbance while forwarding had stronger impacts. However, it should be noted that these impact levels are found only on approximately $28 \%$ of the surface where operations were carried out. From the evidence gathered in this study, winching seems a less impactful extraction method in the studied context. On the other hand, to decrease the impact of forwarding, some technical adjustments such as bogie-tracks, as well as improved operator training, should be applied.
\end{abstract}

Keywords: sustainable forest operations; sustainable forest management; QBS-ar index; winching; forwarder

\section{Introduction}

Forests are crucial in the ecosystem of our planet. In fact, they provide not only timber products but also several ecosystem services [1] such as carbon balance, hydrological protection, recreational opportunities and habitat provision [2-4]. To allow forests to perform their fundamental services, it is crucial to manage them properly by applying sustainable forest management (SFM) [5]. When speaking of SFM, it is intended that this type of management allows forests to maintain and enhance their economic, social and environmental value for the benefit of present and future generations [6].

Several approaches and behaviors can be helpful to achieve SFM. Among these are innovating silvicultural treatments [7], valorizing residues through the development of 
innovative by-products [8] and adopting close-to-nature silviculture [9]. Another beneficial and fundamental approach in this context is developing sustainable forest operations (SFOs). This means practicing forest logging in a way that ensures high productivity and low costs (economic pillar), reduced impact on the environment referred to as the environmental pillar and safe working conditions for the operators that is the social pillar $[10,11]$.

The application of SFOs is particularly necessary to achieve SFM. Without sustainable forest utilization, it is impossible to guarantee the health of the forest ecosystem [12,13].

One of the main issues when putting SFOs into practice is limiting the impact on forest soil caused by logging [14]. Soil compaction because of forest operations that can lead to hydrological issues of increased runoff and sediment yield [15,16], including the improper development of natural regeneration with decreased seedling biomass and root length [17].

Several studies have been conducted to evaluate such impacts, and there is a wide range of literature on the topic $[18,19]$. The evaluation of the implications of different silvicultural practices and harvesting methods on forest soil has been one of the most important research topics in the sector of forest engineering since the 1980s [20-23].

Nonetheless, there is still much to investigate regarding the issue of soil impacts related to forest logging. Indeed, the major part of the current literature is focused on coniferous stands, considering the generally higher economic importance of this type of forest. Furthermore, while the implications of logging on physico-chemical soil properties have been widely investigated, only a few studies focused on impacts to soil biological features [24]. For example, using the QBS-ar index (soil biological quality index based on microarthropods) has shown very interesting features as an indicator of impacts on soil edaphic fauna after logging $[25,26]$.

Finally, few studies [27-29] have been reported in the literature regarding the comparison of different harvesting systems working in the same conditions (studying the same intervention in the same area to evaluate soil impacts related to the different machineries).

Regarding this topic, Allmann et al. [27] compared the impacts to soil bulk density after logging with different forwarders and skidders in several soil conditions, highlighting that different machines led to similar kinds of impact on soil physical features. Eroğlu et al. [28] studied the impacts of three different extraction systems (cable yarder, skidder and chute system) in a spruce forest in Turkey. These reported higher impacts in the ground-based extraction via skidder in comparison to the other systems. Some years later Picchio et al. [29] evaluated three different extraction systems (cable yarder, forestry fitted farm tractor, with winch and horse) concerning physico-chemical and biological impacts after a strip clear cut in a pine stand, reporting the lowest impact for cable yarder and tractor with winch.

Among the studies reported above [27-29], no one focused on hardwood species managed as high forest and treated with the shelterwood system. This may be due to the fact of the higher economic importance that softwood stands are currently showing. However, the climate change scenarios forecast for the following decades predict a substantial impact of global warming on coniferous species. A consequent increased attention toward the silviculture of hardwood species for silvicultural issues is expected, especially regarding beech (Fagus sylvatica L.) [30,31].

On the other hand, there is still much to do regarding the deep understanding of impacts related to logging in beech stands, mostly regarding biological issues in European forests [18].

Indeed, several studies have been conducted to assess forest utilization impacts on soil in beech forests, but the major part of these has been carried out outside Europe without taking into consideration soil biological features [16,32,33]. Furthermore, very little attention has been given to the evaluation of the impact on forest soil in beech stands of cut-to-length (CTL) machineries, as forwarders, except for one study dated 2003 referring to data from 1989-1991 [34].

This last mentioned is a very important aspect considering that in the last few years CTL machineries have been introduced in hardwood stands. Until recently this system was exclusively used in softwood stands, mostly in the Mediterranean context. Obviously, 
there is still much to investigate in the application of CTL machineries in a sustainable way in hardwood stands [35-38].

Considering all the literature, the objective of this study was to evaluate the physicochemical and biological impact on the forest soil in Mediterranean beech forests, because of forest logging with two different extraction systems, which are forestry-fitted farm tractors equipped with winch and forwarder.

There are several innovative aspects in this study. First, this is the first work that considered the impact on soil fauna in beech forests. Second, this is the first comparative study between the winching-skidding method and forwarding in this type of stand. Finally, this represents the first evaluation of soil impact after ground-based extraction to beech stands carried out in the Mediterranean context. The research was developed following the methodology proposed in scientific studies on the same topic and highlighted also by Picchio et al. [18].

The research hypothesis supported by the standardized experimental design can be summarized as: (i) the ground-based extraction system has a significant impact on soil physico-chemical and biological properties with a short time perspective; (ii) the impact related to forestry is lower than the one triggered by forest logging. Moreover, a further question for research is as follows: which is the most soil friendly ground-based logging method in similar conditions, winching-skidding or forwarding?

\section{Materials and Methods}

\subsection{Study Area}

The study area is located on Mount Amiata in the region of Tuscany in Italy (coordinate in WGS84UTM32T 713,319 E; 4,750,291 N). It consists of two different subcompartments of the forest management plan of the Forest Consortium of Amiata, a public entity that manages all the public forests of the district of Grosseto, which includes Mount Amiata and some private ones. Both subcompartments are even-aged beech stands managed as high forest and treated as shelterwood systems (Figure 1). In both parcels the intervention consisted of a late thinning from below carried out throughout the entire surface of the subcompartment. Along with beech, there is the sporadic presence of silver fir (Abies alba Mill.), sweet chestnut (Castanea sativa Mill.) and wild cherry (Prunus avium L.). Soil texture is the same in both parcels, and the soil can be classified as sandy loam. Topographic features are also the same in the two subcompartments, with limited roughness and medium slope (prevalent slope $28 \%$ ).

Both stands underwent the same type of intervention. The stands were also very close in age: one stand was 102 years, and the other was 106 years. The preintervention average dbh (diameter at breast height) was $45 \mathrm{~cm}$, average height $26.6 \mathrm{~m}$, stand density $149 \mathrm{n}^{\circ}$ ha $^{-1}$ and standing volume $311.010 \mathrm{~m}^{3} \mathrm{ha}^{-1}$ in both parcels. Harvested volume was also very similar, accounting for about $25 \%$ of the standing volume in both subcompartments.

The two subcompartments were both harvested in 2020 by forest operators with similar working experience ( $>15$ years). Felling and processing were carried out in both subcompartments in a motor-manual way by chainsaw. Extraction operations were performed with different systems. The CTL extraction system was performed by a forwarder (FORW) in the subcompartment n. 3, while in the subcompartment n. 6, the tree length system (TLS) was applied by a forestry-fitted farm tractor equipped with forest winch (WINCH). These systems represent the most applied harvesting machineries for logging activities in Mediterranean beech forests [36,39]. Indeed, while until some years ago winching was practically the only option for forestry interventions in beech high forests, in the last years there has been a growing application of forwarders [40]. Technical characteristics of the applied machineries are reported in Table 1. 


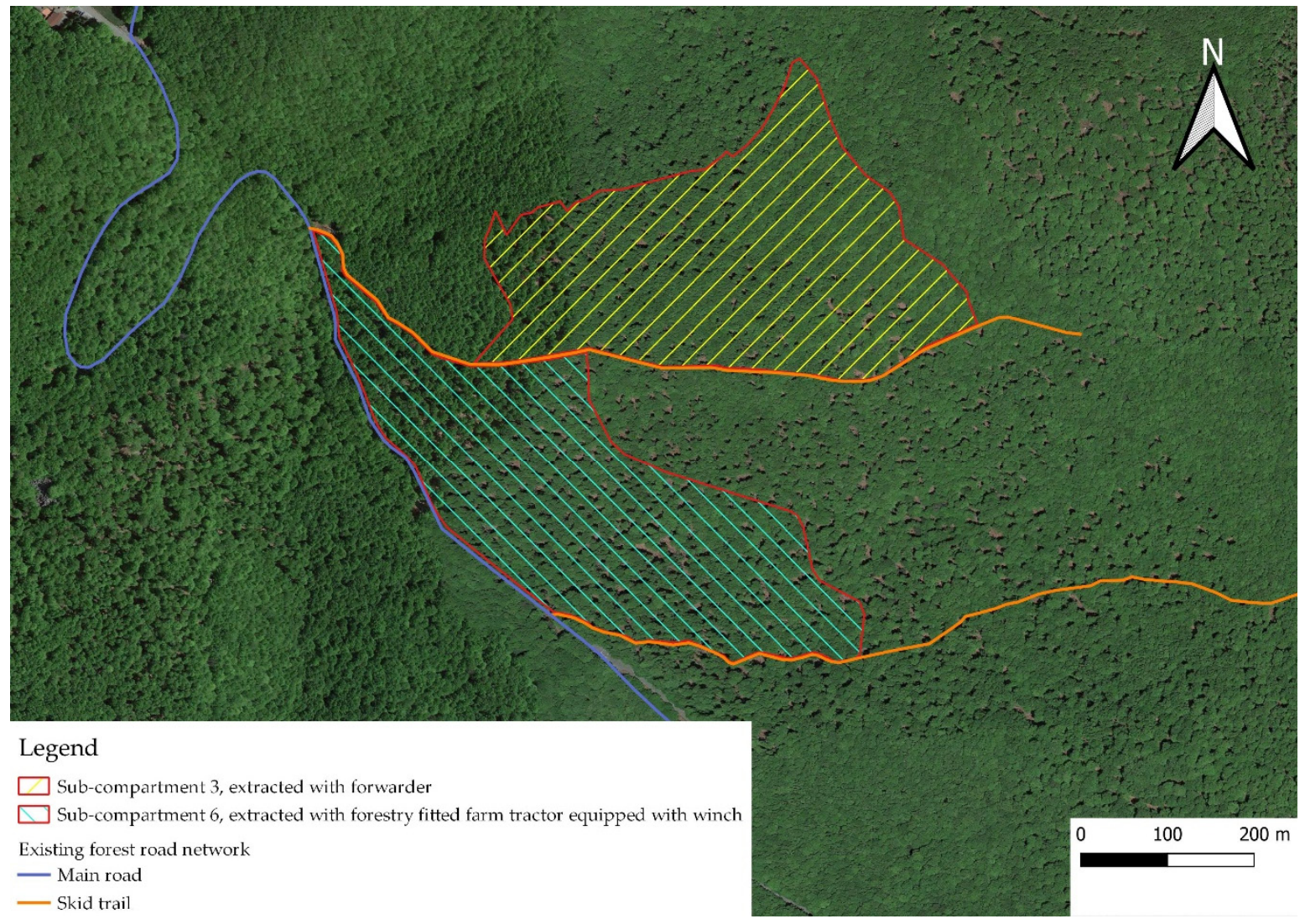

Figure 1. Study area. The boundaries of the two subcompartments are reported in red. The parcel extracted with a forwarder has yellow lines, while the one in which extraction was performed via winching has light blue lines. In the figure the existing road network before harvesting is shown. Blue line is for the main road, and the orange line is for the existing skid trails.

Table 1. Technical features of the applied machineries for WINCH and FORW experimental treatments and main average operative data $( \pm \mathrm{SD})$.

\begin{tabular}{ccc}
\hline Parameter & WINCH & FORW \\
\hline Machine type & Forestry-fitted farm tractor & Forwarder \\
Machine model & Landini 135DT & John Deere 1110D \\
Engine power & $98 \mathrm{~kW}$ & $120 \mathrm{~kW}$ \\
Equipment & $60 \mathrm{kN} \mathrm{Schwarz} \mathrm{EGV} \mathrm{60} \mathrm{forest} \mathrm{winch}$ & n.a. \\
Empty weight & $6400 \mathrm{~kg}$ & $15,370 \mathrm{~kg}$ \\
Average load for cycle & $1580.9 \pm 237.6 \mathrm{~kg}$ & $10,411.7 \pm 729.4 \mathrm{~kg}$ \\
Average distance for cycle & $195.8 \pm 7.7 \mathrm{~m}$ & $273.9 \pm 10.1 \mathrm{~m}$ \\
\hline
\end{tabular}

Two different areas were identified in each subcompartment. The disturbed area (DIST) consisted of all the forest surface directly affected by logging activities, which were skid trails, strip roads and winching corridors. The undisturbed area (UND) was represented by the soil affected only by the silvicultural activity for instance the logging gaps without winching corridors. Moreover, a third area used as control (CON) was identified. This was a forest close to the two subcompartments, which in this case were properly adjacent and with the same topography, soil and stand features. No harvesting operations had not been carried out in this area in the last 30 years. This approach allowed us to separately evaluate the impacts related to the silviculture treatment in itself (UND) with the impacts caused by the proper forest operations (DIST). All the parameters mentioned below were properly evaluated by considering this experimental design. 


\subsection{Investigated Variables}

First, the assessment of the percentage of soil affected by the utilization was carried out for both FORW and WINCH. To perform this evaluation six linear transects were established in each subcompartment. Each transect was rectangular in shape $(1 \mathrm{~m} \times 200 \mathrm{~m})$ and defined using a compass and tape measure. Along the transect, visual inspection was conducted for the presence or absence of bent understory, crushed litter, ruts, or soil mixing and was applied to discriminate between disturbed soil and undisturbed soil. Data were subsequently referred as the percentage of disturbed soil on the overall surface of the transect.

The impact on the soil was evaluated on six randomly selected sample plots per treatment (FORW-DIST; FORW-UND; WINCH-DIST; WINCH-UND; CON). Sample plots consisted of circular areas of a $15 \mathrm{~m}$ radius, totaling a surface of $706.5 \mathrm{~m}^{2}$. The parameters investigated of the soil physico-chemical properties were penetration resistance (PR), shear resistance (SR), bulk density $(\mathrm{BD})$ and organic matter $(\mathrm{OM})$. Biological impacts were assessed applying the QBS-ar index. The field survey was carried out in June 2021, about one year after the end of the harvesting operations in both parcels.

\subsection{Soil Physico-Chemical Properties}

$\mathrm{PR}(\mathrm{MPa})$ and SR $\left(\mathrm{Mg} \mathrm{m}^{-2}\right)$ were evaluated by a handheld dedicated instrument in the first 3-10 cm of soil. Obtained values for PR and SR were referred to the soil water-holding capacity as suggested by Saxton et al. [41]. For both PR and SR 18, measurements were taken in each experimental treatment and six measurements in the control zone.

$\mathrm{BD}\left(\mathrm{g} \mathrm{cm}^{-3}\right)$ were assessed by sampling the soil with a dedicated corer (18 soil samples in each experimental treatment and six samples in the control area). Then soil samples were sealed in plastic bags and shipped to the laboratory for weighing after oven drying at $105^{\circ} \mathrm{C}$ to constant weight (dry weight). The dry weight divided by the volume of the cylinder $\left(100 \mathrm{~cm}^{3}\right)$ gives the BD [42].

Organic matter (OM, \%) evaluation was carried out by collecting 12 soil samples in each experimental treatment and six in the control area. Each sample was collected with the same corer applied for bulk density, put into a plastic bag and shipped to the laboratory. $\mathrm{OM}$ assessment was carried out with the incineration method in a mitten at $400{ }^{\circ} \mathrm{C}$ for $4 \mathrm{~h}$,

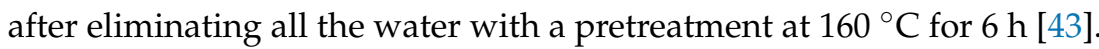

\subsection{QBS-ar Index Evaluation}

Regarding biological impacts, the QBS-ar index was applied. This is a qualitative index that evaluates the complexity of the soil microarthropod community.

This index is based on the concept that the higher the soil quality, the higher the number of microarthropod groups present as they are adapted to the soil environment. Soil microarthropods are separated into several biological forms according to their morphological adaptation to soil habitats. Each form is linked with a score named EMI (eco-morphological index), that ranges from 1 to 20 in proportion to the degree of adaptation [43]. The QBS-ar index value is the sum of the EMI of all found groups. To assess the QBS-ar index, three soil cores $100 \mathrm{~cm}^{2}$ and $10 \mathrm{~cm}$ deep were sampled with a dedicated corer in each area. Subsequently, microarthropods were extracted with a Berlese-Tüllgren funnel. The various specimens were collected in a preserving solution (75\% ethyl alcohol and $25 \%$ glycerol by volume) and identified with different taxonomic levels (class for Myriapoda and order for Insecta, Chelicerata and Crustacea) using a stereo microscope.

\subsection{Statistical Analysis}

After checking for data normality (Shapiro-Willk test) [44] and homoscedasticity (Levene test) [45], the presence of statistically significant differences among the mean values of treatments was investigated with unpaired samples T-test (for the percentage of impacted surface) [46] and one-way analysis of variance (ANOVA, for the other investigated variables) [47]. An HSD Tukey test was applied post hoc [48]. Data which did not show normal 
distribution, or which presented insufficient homogeneity of variance, were statistically processed using the nonparametric ANOVA Kruskal-Wallis test [49] applying the Duncan test [50] post hoc. Furthermore, a principal component analysis (PCA) [51] was performed to investigate any linear correlations between the treatments. To minimize the scaling effect because of different measurement units, the data of each independent variable were standardized using box-cox transformation.

Statistical analysis was carried out with Statsoft Statistica 7.0 (Statsoft, Tulsa, OK, USA) [52] and PAST software [53].

\section{Results and Discussions}

Both extraction systems led to a similar percentage of impacted surface (Figure 2). In detail, ground-based operations via winching and forwarding impacted about $28 \%$ of the overall surface, with values in line with similar systems applied in different conditions $[25,54,55]$. The low tree density of the investigated stands did not lead to a lower percentage of impacted surface. This was rather expected for the forwarder, considering the short working distance of this system, i.e., 10-12 m [36], forces the operator to extensively drive the machine along the stand. On the contrary, winching in the presence of a stand with low density (around 100 trees per hectare after the intervention) would assume a lower impacted surface, considering the possibility of winching on longer distances. It is probable that the obtained results, which do not confirm this assertion, are related to the limited application of snatch blocks which are effective solutions to reduce tree and soil damages during winching [56]. These results therefore suggest the importance of the application of best management practices during forest operations, considering that these are effective solutions to mitigate the negative impact of logging [57-59].

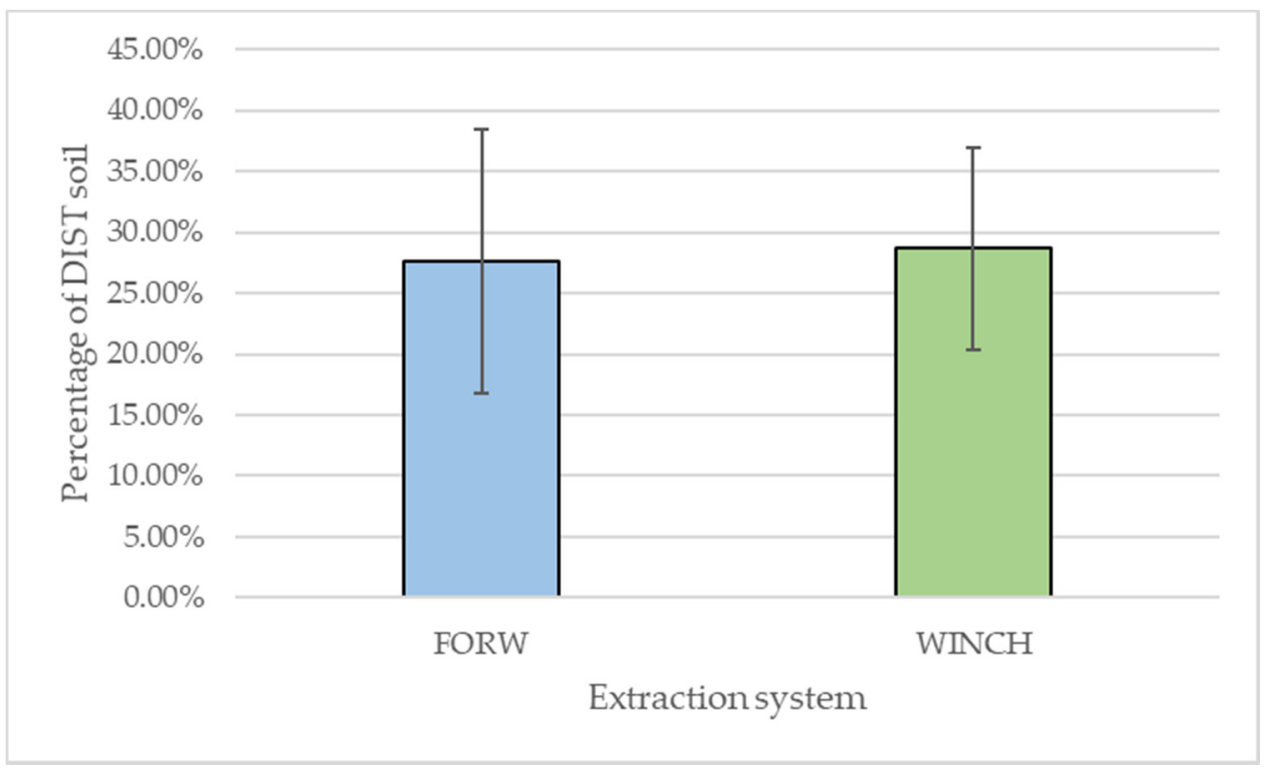

Figure 2. Percentage of impacted surface with the two analyzed extraction systems. No statistically significant difference was detected according unpaired samples $t$-test $(p<0.05)$. FORW: extraction with forwarder; WINCH: extraction with forestry-fitted farm tractor equipped with winch.

Data on soil bulk density in the different treatments are given in Figure 3. Note that BD is higher than $\mathrm{CON}$ for both disturbed and undisturbed soil for both extraction systems. Soil affected by forwarder passage (FORW-DIST) showed higher bulk density than WINCHDIST, suggesting a higher impact related to the CTL machinery on soil bulk density. On the other hand, as expected, no difference was revealed between the two UND soil portions, considering that the silviculture treatment and the magnitude of intervention and canopy removal was the same for the two investigated forest subcompartments. Impact level in UND soil is indeed related to the degree of canopy cover removal [60,61]. 


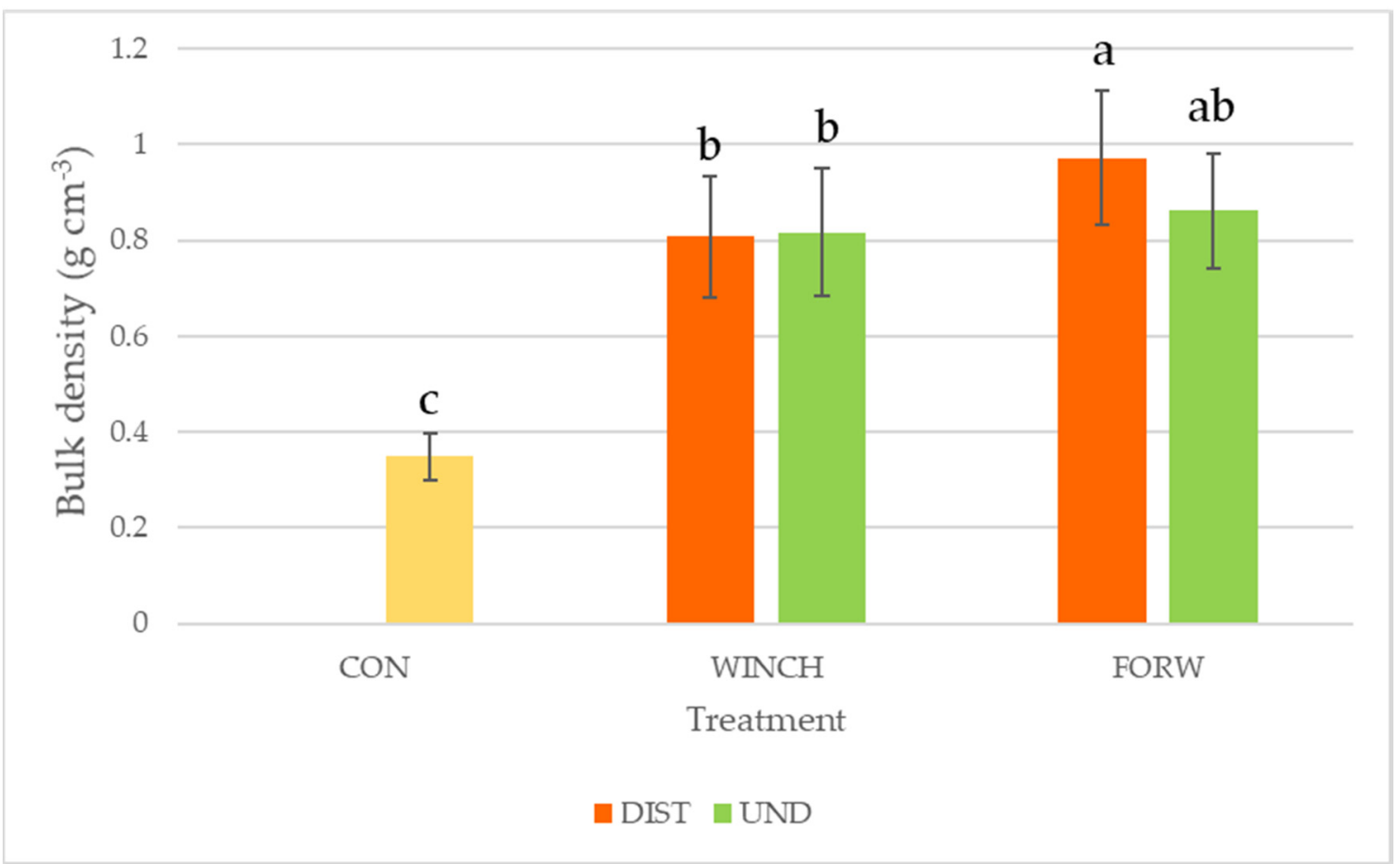

Figure 3. BD for the different treatments. Different letters indicate different homogeneous group according to an HSD Tukey test $(p<0.05)$ : CON: control area; WINCH: winching; FORW: forwarding; DIST: soil directly affected by machineries' passage; UND: soil in the harvested parcels but not directly affected by machineries' passage.

Focusing on the comparison between the two applied extraction systems, it is possible to assert that obtained results are consistent with what was reported by Venanzi et al. [62] concerning a comparison of soil impact related to winching and forwarding in a Mediterranean turkey oak (Quercus cerris L.) coppice. Authors of this publication revealed a higher increase in soil bulk density triggered by forwarding operations compared to extraction by winching-skidding. On the other hand, the obtained findings are not consistent with the common assertion that an advanced mechanization level leads to decreased impact on the soil. Therefore, it can be speculated that the lower impact reported in current literature for machinery specifically dedicated to forestry [14] could be related more to the correct application of specific tools to decrease soil damage that is caused by the tires of the forwarders, for instance bogie tracks [12,26]. Without such specific adjustments, the higher number of passages per volume unit needed to extract timber with the CTL system in comparison to the TLS system seems to lead to higher soil disturbance.

Surprisingly, the magnitude of machinery-induced soil compaction found in this study is three times higher than CON values for both WINCH and FORW, which is higher than what was reported in current literature. Indeed, a recent meta-analysis on the topic revealed an average increase in bulk density after forest utilization of 5-15\% [63], while a previous study carried out in Iran on oriental beech stands reported an average increase of 19-39\% [64]. This suggests a high sensitivity of the soil of the Mediterranean beech forests to ground-based extraction, which should be evaluated carefully in future studies along with an evaluation of the time needed for recovery.

Data on PR and SR are reported in Figure 4. The obtained results suggest a significant impact related to forest utilisation for both variables, but not an influence because of silvicultural activities. Indeed, regarding PR, FORW-DIST and WINCH-DIST were significantly higher than CON with no difference between them. Concerning SR, FORW-DIST was significantly higher than CON, while no difference was detected for WINCH-DIST. From these results it can be speculated that there is a rather clear impact on both PR and SR related to forest utilization, and the magnitude of this impact is not related to the applied 
machinery. Interestingly, no impact related to the silviculture in itself was detected for both WINCH-UND and FORW-UND, which is consistent with what was reported in a recent similar study carried out in a different kind of stand [62].
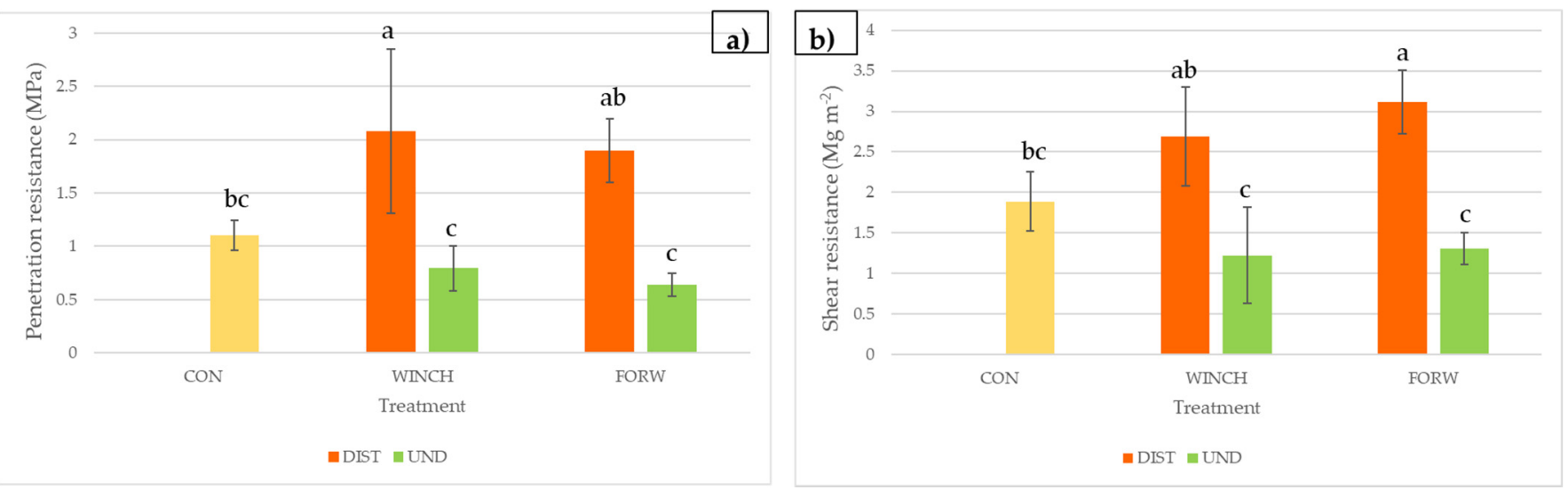

Figure 4. PR (a) and SR (b) for the different treatments. Different letters indicate different homogeneous group according to an HSD Tukey test $(p<0.05)$ : CON: control area; WINCH: winching; FORW: forwarding; DIST: soil directly affected by machineries' passage; UND: soil in the harvested parcels but not directly affected by machineries' passage.

Interesting results were also obtained concerning OM (Figure 5). A significant impact of forest utilization was revealed for both winching and forwarding. Furthermore, FORWDIST values were significantly lower than WINCH-DIST ones, suggesting that a higher impact on soil OM occurred in the extraction via forwarder, as found by Venanzi et al. [62], but different from what was reported by another similar study carried out on chestnut (Castanea sativa Mill.) coppice [26]. Regarding OM, silviculture in itself caused a significant impact. Indeed, both WINCH-UND and FORW-UND showed lower values than CON (with no differences between them as expected). From the obtained results it seems that also the limited canopy gaps created by thinning interventions can lead to a decreased soil $\mathrm{OM}$ in the first year after harvesting.

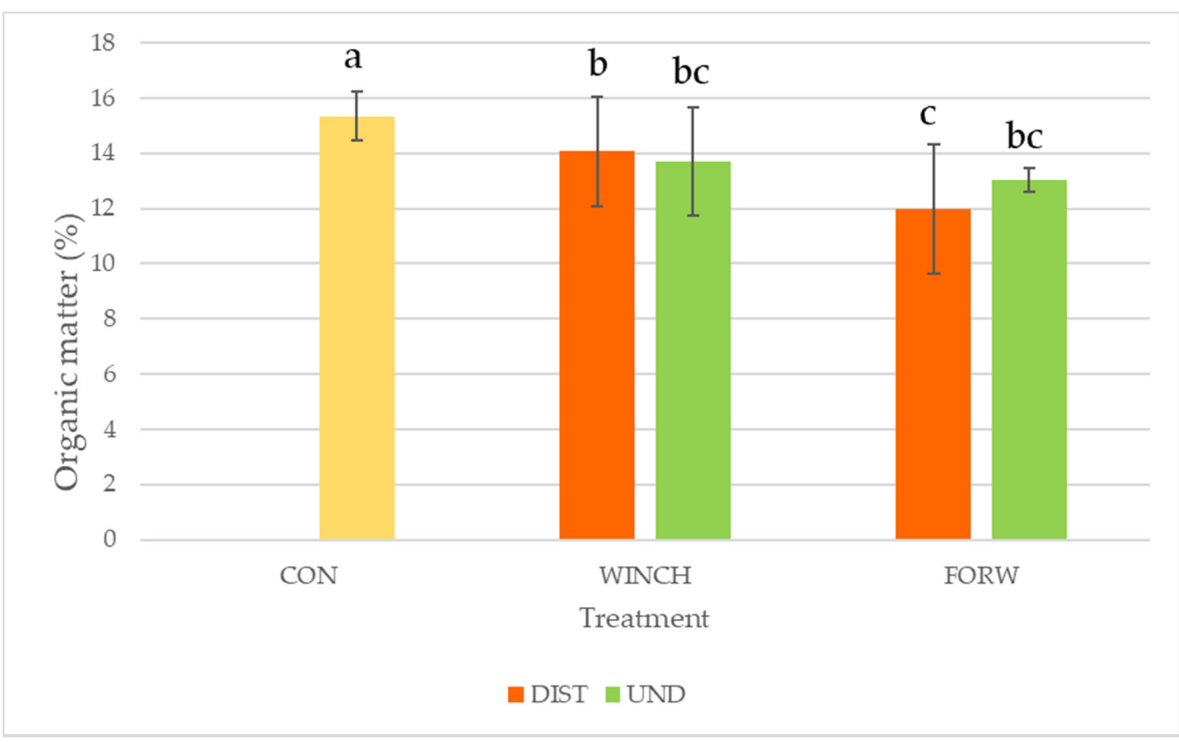

Figure 5. OM for the different treatments. Different letters indicate different homogeneous groups according to an HSD Tukey test $(p<0.05)$ : CON: control area; WINCH: winching; FORW: forwarding; DIST: soil directly affected by machineries' passage; UND: soil in the harvested parcels but not directly affected by machineries' passage. 
Data on the impact on soil biological features are given in Figure 6. As is shown, only WINCH-DIST had a significant impact in comparison to CON. A trend can therefore be observed which is inverse to what is seen for the major part of the other parameters analyzed in the present study. Interestingly, and in contrast with similar studies carried out with the same methodology but in different kinds of stands in the Mediterranean area $[25,26,62]$, silviculture in itself does not lead in the short-term to a decrease in the biodiversity of soil edaphic fauna, and WINCH-UND and FORW-UND values are not different from CON. This could be related to the low litter decomposition rate typical of beech $[65,66]$, along with the fact that the studied stands were not affected by interventions at least for 40 years before the harvesting intervention. This led to the creation of a thick layer of litter, which acted as a sort of protective buffer, limiting the amount of light radiation reaching the soil and thus decreasing the disturbance to soil edaphic fauna. Obviously, further dedicated studies are needed to confirm this hypothesis and to assess its validity with a longer time perspective.

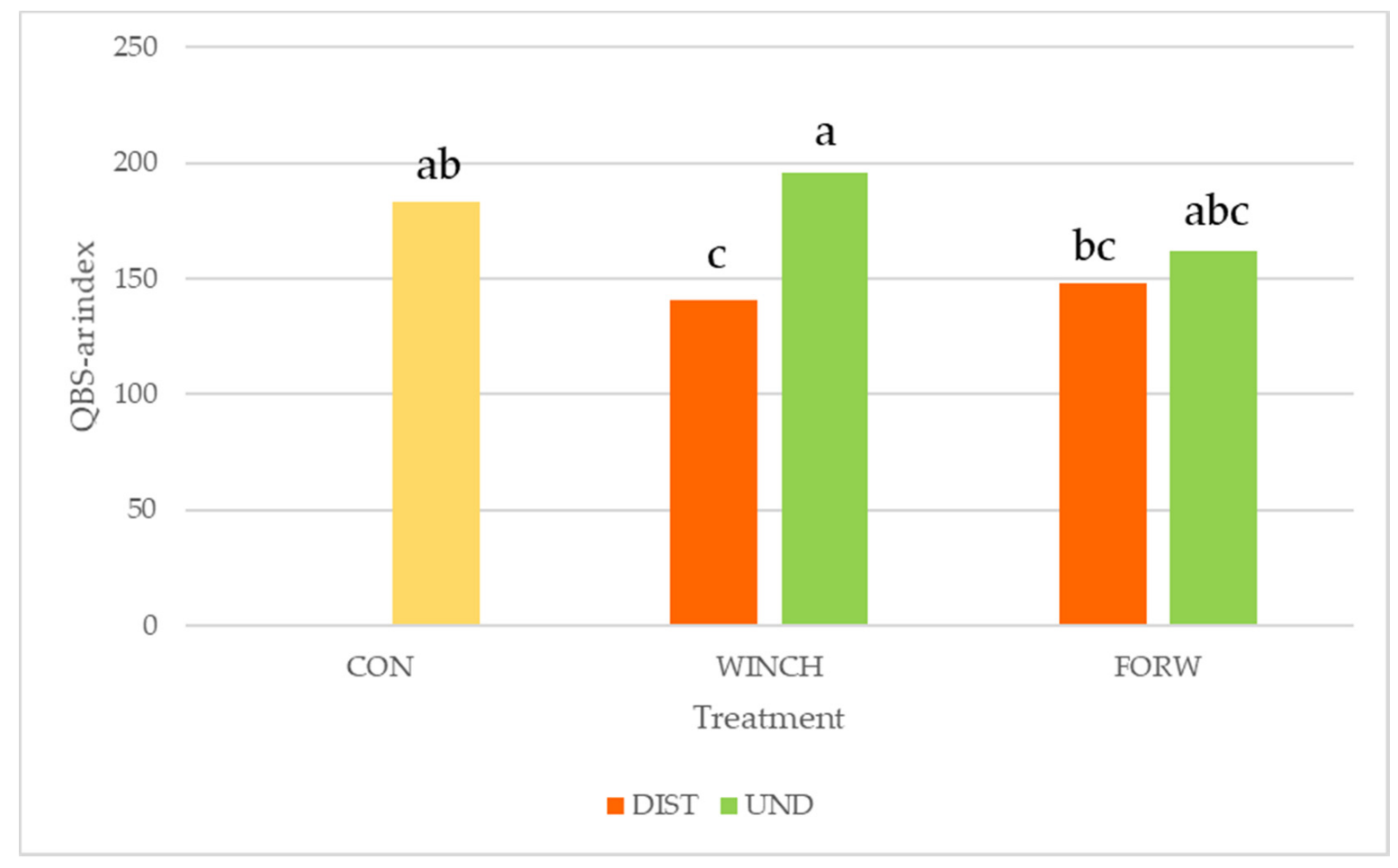

Figure 6. QBS-ar index values for the different treatments. Different letters indicate different homogeneous group according to the Duncan test $(p<0.05)$ : CON: control area; WINCH: winching; FORW: forwarding; DIST: soil directly affected by machineries' passage; UND: soil in the harvested parcels but not directly affected by machineries' passage.

Focusing on an overview of the data found, Figure 7 shows the results of the principal Ccmponents analysis (PCA) to summarize the findings obtained in a comprehensive graphical framework. The two principal components PC1 and PC2 explained 48\% and 26\% of the total variance, respectively. It is evident how the undisturbed areas are close to the control one, while disturbed zones are more distant, thus highlighting a higher impact on the soil features. Moreover, the distance from the CON as compared to the WINCH-DIST, showed that FORW-DIST had a greater impact. 


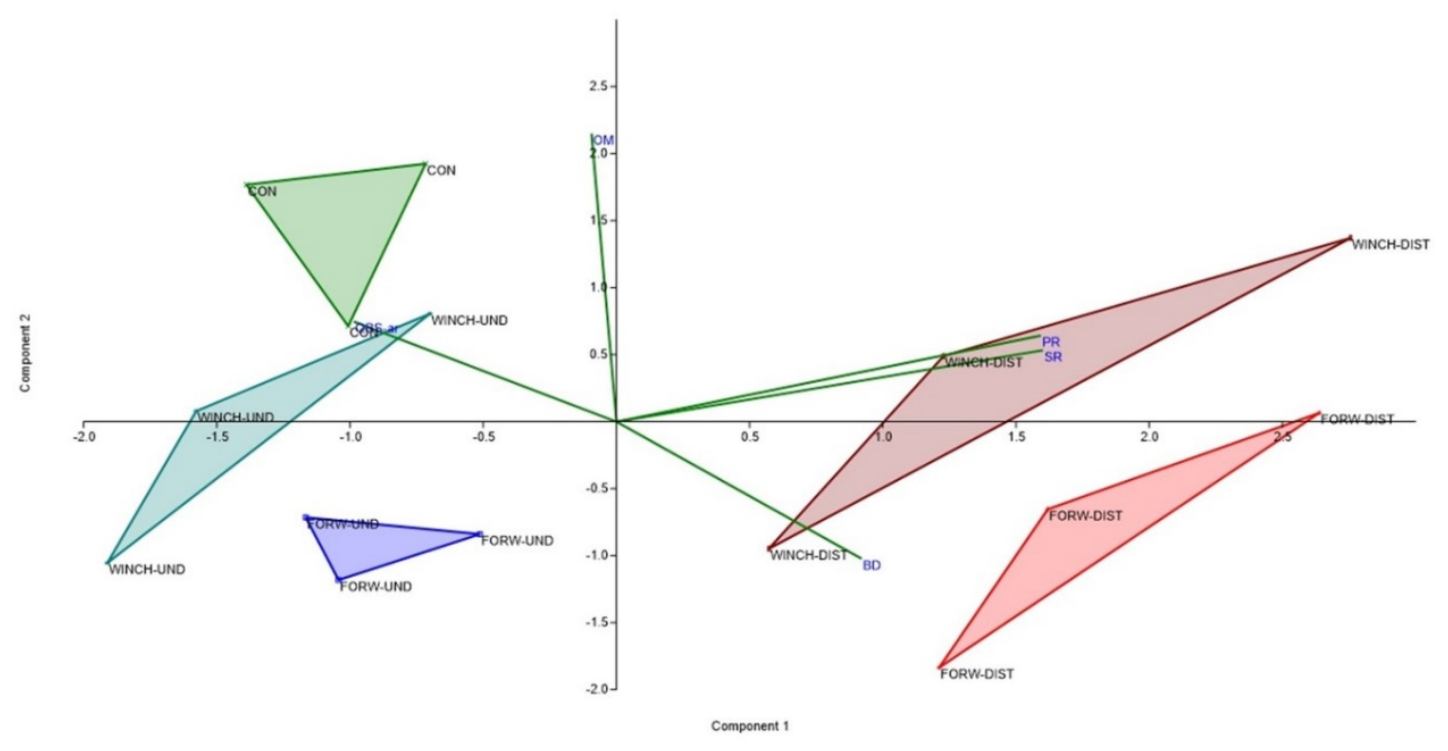

Figure 7. Score plot of components PC1 and PC2 of the principal component analysis referred to the investigated soil variables. Control area is reported in green; WINCH-UND in light blue; FORW-UND in dark blue; WINCH-DIST in dark red and FORW-DIST in light red. Green lines indicate the Biplot.

To summarize, this was the first study aimed at evaluating in the short-term the impact triggered by two different harvesting systems in Mediterranean beech forests, focusing on both physico-chemical and biological disturbances. The applied experimental design allowed for the separate assessment of the impact related to the applied machineries (DIST soil) and of the ones related to forestry (UND soil). The first aspect which is worth highlighting is that the impacts related to forestry are much lower than the ones related to forest operations. The disturbance in UND soil was indeed evident for bulk density and organic matter but not for penetration resistance, shear resistance and, interestingly, for QBS-ar index. Focusing on the comparison between the two applied harvesting systems, winching with a forestry-fitted farm tractor showed the ability to trigger lower disturbance than forwarding. This statement is rather in contrast with current literature on the topic [14], which suggests that machinery specifically developed for forest operations are less impactful than adapted agriculture machinery. Instead, in the present study forwarding resulted in more impact than winching, particularly concerning increased bulk density and organic matter depletion. In this specific case, the difference can be attributed to two factors. First, the CTL system applied with the forwarder needs more passages to extract the same volume of material [67], thus triggering higher soil compaction [63]. Second, the application of CTL machineries, such as forwarders, in Mediterranean forestry has been growing extensively only in the last few years [36]. Therefore, operators could be still not be fully skilled with the proper application of these machineries, as well as with the technical adjustments which can decrease soil damages (such as, for example, the application of bogie tracks or the placement of logging residues on the strip roads to decrease soil compaction) [12]. This highlights the need of increasing operators' skills concerning these modern machineries in Mediterranean context, suggesting the importance of the collaboration between forest researchers, technicians and operators, in implementing effective sustainable forest management $[68,69]$.

\section{Conclusions}

Research conducted on this topic is of great interest. Findings give a precious insight into the topic of "forest harvesting best practices". The increase in knowledge for better sustainable forest management supports the decision making of managers and stakeholders. This is of particular importance when dealing with alterations to soil features that are related to logging activities, which are defined as soil disturbances or soil impacts. 
The data acquired from these case studies are important for updating meta-analysis research, guidelines, criteria and indicators for SFOs applications.

As found in other studies, the physical, chemical, and biological soil features were slightly disturbed by the forestry itself, as expected from continuous forest-cover silviculture. Forest operations and machine traffic showed clear disturbance through the mechanical action on the soil structure, resulting in a substantial alteration to the soil characteristics.

Between the two extraction techniques observed, winching caused lower disturbance while forwarding had stronger impacts. This result is probably related to the different applied harvesting systems, TLS and CTL, with the need for CTL to make more passages per unit of volume. TLS application via winching seems therefore a solution able to trigger lower disturbance to soil in the short-term. On the other hand, to increase the sustainability of forwarding in Mediterranean beech forests, applying bogie-tracks and increasing operator training could be possible solutions.

However, it should be noted that these impact levels are found, for both machineries, on approximately $28 \%$ of the surface. Furthermore, although short-term impacts are substantial for both systems, data from the literature suggests a recovery time that should not last longer than 5-8 years. However, further research is needed to test this hypothesis.

Author Contributions: Conceptualization, F.L., R.V. and R.P.; methodology, F.L., R.V., D.T., W.S. and R.P.; formal analysis, F.L. and R.P.; writing-original draft preparation, F.L., R.V., D.T. and W.S.; writing-review and editing, F.L., R.V., W.S. and R.P.; supervision, R.P. All authors have read and agreed to the published version of the manuscript.

Funding: This research received no external funding.

Institutional Review Board Statement: Not applicable.

Informed Consent Statement: Not applicable.

Data Availability Statement: The data presented in this study are available on request from the corresponding author.

Acknowledgments: The authors gratefully acknowledge Forest Consortium of Amiata, ArcidossoItaly. This research was in part carried out within the framework of the MIUR (Italian Ministry for Education, University and Research) initiative "Departments of Excellence" (Law 232/2016), WP3, which financed the Department of Agriculture and Forest Science at the University of Tuscia. This research was in part carried out within the project PLANNING CHANGE (CAMBIO PIANO), PSR 2014-2020 Tuscany Region, met. Leader. Meas. 16.2-Gal F.A.R. Maremma.

Conflicts of Interest: The authors declare no conflict of interest.

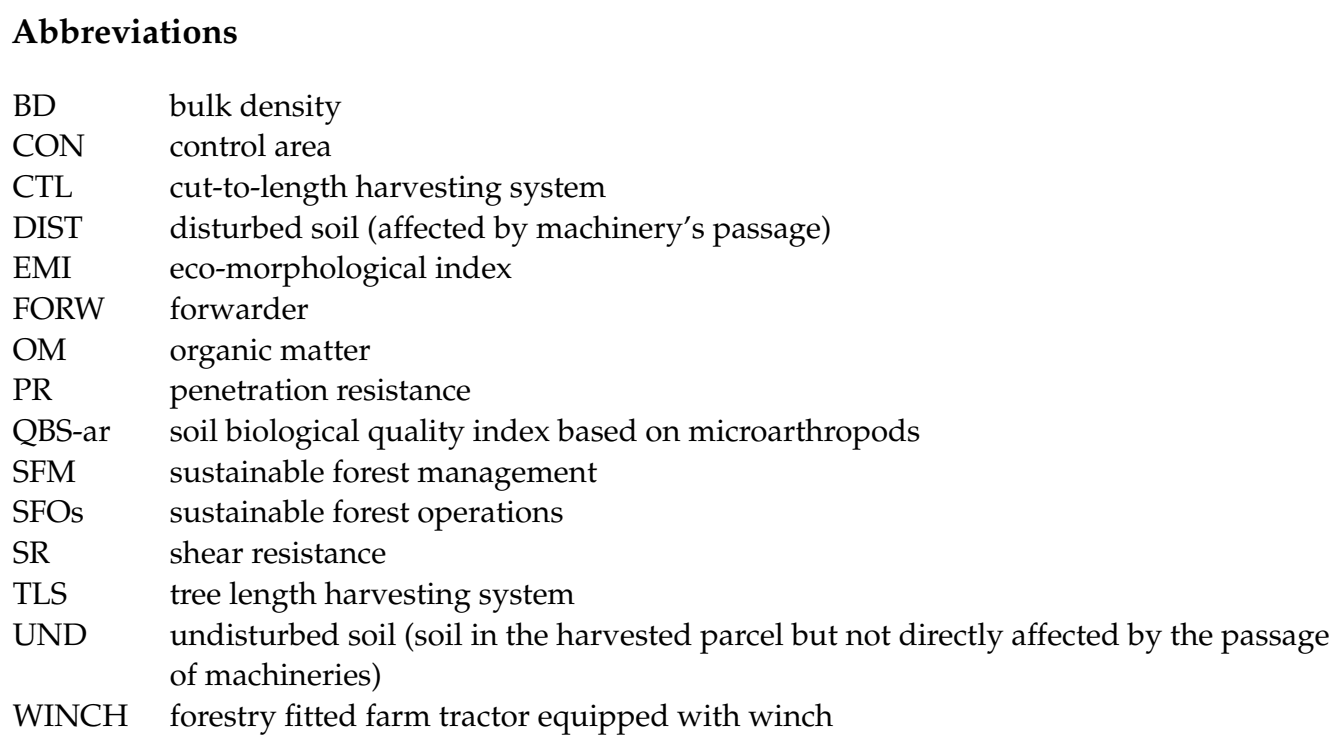




\section{References}

1. Simons, N.K.; Felipe-Lucia, M.R.; Schall, P.; Ammer, C.; Bauhus, J.; Blüthgen, N.; Boch, S.; Buscot, F.; Fischer, M.; Goldmann, K.; et al. National Forest Inventories capture the multifunctionality of managed forests in Germany. For. Ecosyst. 2021, 8, 5. [CrossRef]

2. Gamfeldt, L.; Snäll, T.; Bagchi, R.; Jonsson, M.; Gustafsson, L.; Kjellander, P.; Ruiz-Jaen, M.C.; Fröberg, M.; Stendahl, J.; Philipson, C.D.; et al. Higher levels of multiple ecosystem services are found in forests with more tree species. Nat. Commun. 2013, 4, 1340. [CrossRef] [PubMed]

3. Miura, S.; Amacher, M.; Hofer, T.; San-Miguel-Ayanz, J.; Ernawati; Thackway, R. Protective functions and ecosystem services of global forests in the past quarter-century. For. Ecol. Manag. 2015, 352, 35-46. [CrossRef]

4. $\quad$ Fitts, L.A.; Russell, M.B.; Domke, G.M.; Knight, J.K. Modeling land use change and forest carbon stock changes in temperate forests in the United States. Carbon Balance Manag. 2021, 16, 20. [CrossRef]

5. Soler, R.; Lorenzo, C.; González, J.; Carboni, L.; Delgado, J.; Díaz, M.; Toro Manríquez, M.D.R.; Alejandro, H.H. The politics behind scientific knowledge: Sustainable forest management in Latin America. For. Policy Econ. 2021, 131, 102543. [CrossRef]

6. FAO; UNEP. The State of the World's Forests 2020: Forests, Biodiversity and People; FAO: Rome, Italy, 2020.

7. Salvati, L.; Becagli, C.; Bertini, G.; Cantiani, P.; Ferrara, C.; Fabbio, G. Toward sustainable forest management indicators? A data mining approach to evaluate the impact of silvicultural practices on stand structure. Int. J. Sustain. Dev. World Ecol. 2017, 24, 372-382. [CrossRef]

8. Janiszewska, D.; Olchowski, R.; Nowicka, A.; Zborowska, M.; Marszałkiewicz, K.; Shams, M.; Giannakoudakis, D.A.; Anastopoulos, I.; Barczak, M. Activated biochars derived from wood biomass liquefaction residues for effective removal of hazardous hexavalent chromium from aquatic environments. GCB Bioenergy 2021, 13, 1247-1259. [CrossRef]

9. Schneider, R.; Franceschini, T.; Duchateau, E.; Bérubé-Deschênes, A.; Dupont-Leduc, L.; Proudfoot, S.; Power, H.; de Coligny, F. Influencing plantation stand structure through close-to-nature silviculture. Eur. J. For. Res. 2021, 140, 567-587. [CrossRef]

10. Marchi, E.; Chung, W.; Visser, R.; Abbas, D.; Nordfjell, T.; Mederski, P.S.; McEwan, A.; Brink, M.; Laschi, A. Sustainable Forest Operations (SFO): A new paradigm in a changing world and climate. Sci. Total Environ. 2018, 634, 1385-1397. [CrossRef]

11. Sohrabi, H.; Jourgholami, M.; Jafari, M.; Shabanian, N.; Venanzi, R.; Tavankar, F.; Picchio, R. Soil recovery assessment after timber harvesting based on the Sustainable Forest Operation (SFO) perspective in Iranian temperate forests. Sustainability 2020, 12, 2874. [CrossRef]

12. Labelle, E.R.; Hansson, L.; Högbom, L.; Jourgholami, M.; Laschi, A. Strategies to Mitigate the Effects of Soil Physical Disturbances Caused by Forest Machinery: A Comprehensive Review. Curr. For. Rep. 2022, 8, 20-37. [CrossRef]

13. Holzfeind, T.; Visser, R.; Chung, W.; Holzleitner, F.; Erber, G. Development and Benefits of Winch-Assist Harvesting. Curr. For. Rep. 2020, 6, 201-209. [CrossRef]

14. Hoffmann, S.; Schönauer, M.; Heppelmann, J.; Asikainen, A.; Cacot, E.; Eberhard, B.; Hasenauer, H.; Ivanovs, J.; Jaeger, D.; Lazdins, A.; et al. Trafficability Prediction Using Depth-to-Water Maps: The Status of Application in Northern and Central European Forestry. Curr. For. Rep. 2022, 8, 55-71. [CrossRef]

15. Picchio, R.; Jourgholami, M.; Zenner, E.K. Effects of Forest Harvesting on Water and Sediment Yields: A Review toward Better Mitigation and Rehabilitation Strategies. Curr. For. Rep. 2021, 7, 214-219. [CrossRef]

16. Jourgholami, M.; Khoramizadeh, A.; Venanzi, R.; Latterini, F.; Tavankar, F.; Picchio, R. Evaluation of Leaf Litter Mulching and Incorporation on Skid Trails for the Recovery of Soil Physico-Chemical and Biological Properties of Mixed Broadleaved Forests. Land 2021, 10, 625. [CrossRef]

17. Mariotti, B.; Hoshika, Y.; Cambi, M.; Marra, E.; Feng, Z.; Paoletti, E.; Marchi, E. Vehicle-induced compaction of forest soil affects plant morphological and physiological attributes: A meta-analysis. For. Ecol. Manag. 2020, 462, 118004. [CrossRef]

18. Picchio, R.; Mederski, P.S.; Tavankar, F. How and How Much, Do Harvesting Activities Affect Forest Soil, Regeneration and Stands? Curr. For. Rep. 2020, 6, 115-128. [CrossRef]

19. Schweier, J.; Magagnotti, N.; Labelle, E.R.; Athanassiadis, D. Sustainability Impact Assessment of Forest Operations: A Review. Curr. For. Rep. 2019, 5, 101-113. [CrossRef]

20. Miller, J.H.; Sirois, D.L. Soil Disturbance by Skyline Yarding vs. Skidding in a Loamy Hill Forest. Soil Sci. Soc. Am. J. 1986, 50, 1579-1583. [CrossRef]

21. Rab, M.A. Soil physical and hydrological properties following logging and slash burning in the Eucalyptus regnuns forest of southeastern Australia. For. Ecol. Manag. 1996, 84, 159-176. [CrossRef]

22. Whitman, A.A.; Brokaw, N.V.L.; Hagan, J.M. Forest damage caused by selection logging of mahogany (Swietenia macrophylla) in northern Belize. For. Ecol. Manag. 1997, 92, 87-96. [CrossRef]

23. Merino, A.; Edeso, J.M.; González, M.J.; Marauri, P. Soil properties in a hilly area following different harvesting management practices. For. Ecol. Manag. 1998, 103, 235-246. [CrossRef]

24. Elie, F.; Vincenot, L.; Berthe, T.; Quibel, E.; Zeller, B.; Saint-André, L.; Normand, M.; Chauvat, M.; Aubert, M. Soil fauna as bioindicators of organic matter export in temperate forests. For. Ecol. Manag. 2018, 429, 549-557. [CrossRef]

25. Venanzi, R.; Picchio, R.; Grigolato, S.; Latterini, F. Soil and forest regeneration after different extraction methods in coppice forests. For. Ecol. Manag. 2019, 454, 117666. [CrossRef]

26. Venanzi, R.; Picchio, R.; Grigolato, S.; Spinelli, R. Soil Disturbance Induced by Silvicultural Treatment in Chestnut (Castanea sativa Mill.) Coppice and Post-Disturbance Recovery. Forests 2020, 11, 1053. [CrossRef] 
27. Allman, M.; Jankovský, M.; Messingerová, V.; Allmanová, Z.; Ferenčík, M. Soil compaction of various Central European forest soils caused by traffic of forestry machines with various chassis. For. Syst. 2015, 24, e038. [CrossRef]

28. Eroğlu, H.; Sariyildiz, T.; Küçük, M.; Sancal, E. The effects of different logging techniques on the physical and chemical characteristics of forest soil. Balt. For. 2016, 22, 139-147.

29. Picchio, R.; Mercurio, R.; Venanzi, R.; Gratani, L.; Giallonardo, T.; Lo Monaco, A.; Frattaroli, A.R. Strip Clear-Cutting Application and Logging Typologies for Renaturalization of Pine Afforestation-A Case Study. Forests 2018, 9, 366. [CrossRef]

30. Dyderski, M.K.; Paź, S.; Frelich, L.E.; Jagodziński, A.M. How much does climate change threaten European forest tree species distributions? Glob. Chang. Biol. 2018, 24, 1150-1163. [CrossRef]

31. Antonucci, S.; Santopuoli, G.; Marchetti, M.; Tognetti, R.; Chiavetta, U.; Garfi, V. What Is Known About the Management of European Beech Forests Facing Climate Change? A Review. Curr. For. Rep. 2021, 7, 321-333. [CrossRef]

32. Tavankar, F.; Picchio, R.; Nikooy, M.; Jourgholami, M.; Naghdi, R.; Latterini, F.; Venanzi, R. Soil natural recovery process and Fagus orientalis lipsky seedling growth after timber extraction by wheeled skidder. Land 2021, 10, 113. [CrossRef]

33. Tavankar, F.; Bonyad, A.E.; Nikooy, M.; Picchio, R.; Venanzi, R.; Calienno, L. Damages to soil and tree species by cable-skidding in Caspian forests of Iran. For. Syst. 2017, 26, 11. [CrossRef]

34. Rohand, K.; Al Kalb, A.; Herbauts, J.; Verbrugge, J.C. Changes in some mechanical properties of a loamy soil under the influence of mechanized forest exploitation in a beech forest of central Belgium. J. Terramech. 2003, 40, 235-253. [CrossRef]

35. Labelle, E.; Breinig, L.; Sycheva, E. Exploring the Use of Harvesters in Large-Diameter Hardwood-Dominated Stands. Forests 2018, 9, 424. [CrossRef]

36. Picchio, R.; Latterini, F.; Mederski, P.S.; Tocci, D.; Venanzi, R.; Stefanoni, W.; Pari, L. Applications of GIS-Based Software to Improve the Sustainability of a Forwarding Operation in Central Italy. Sustainability 2020, 12, 5716. [CrossRef]

37. Bustos-Letelier, O.; Mena, C.; Bussenius, W.; Briceño, M. The Influence of Old and New Machines on Productivity and Costs of Four Yarding Methods in Small-Scale Forestry in a Maine Forest. Small-Scale For. 2021, 20, 97-117. [CrossRef]

38. Mederski, P.S.; Borz, S.A.; Đuka, A.; Lazdinš, A. Challenges in forestry and forest engineering-Case studies from four countries in East Europe. Croat. J. For. Eng. 2020, 42, 117-134. [CrossRef]

39. Picchio, R.; Pignatti, G.; Marchi, E.; Latterini, F.; Benanchi, M.; Foderi, C.; Venanzi, R.; Verani, S. The Application of Two Approaches Using GIS Technology Implementation in Forest Road Network Planning in an Italian Mountain Setting. Forests 2018, 9, 277. [CrossRef]

40. Ursić, B.; Vusić, D.; Papa, I.; Poršinsky, T.; Zečić, Ž.; Đuka, A. Damage to Residual Trees in Thinning of Broadleaf Stand by Mechanised Harvesting System. Forests 2022, 13, 51. [CrossRef]

41. Saxton, K.E.; Rawls, W.; Romberger, J.S.; Papendick, R.I. Estimating generalized soil-water characteristics from texture. Soil Sci. Soc. Am. J. 1986, 50, 1031-1036. [CrossRef]

42. Marchi, E.; Picchio, R.; Mederski, P.S.; Vusić, D.; Perugini, M.; Venanzi, R. Impact of silvicultural treatment and forest operation on soil and regeneration in Mediterranean Turkey oak (Quercus cerris L.) coppice with standards. Ecol. Eng. 2016, 95, 475-484. [CrossRef]

43. Venanzi, R.; Picchio, R.; Piovesan, G. Silvicultural and logging impact on soil characteristics in Chestnut (Castanea sativa Mill.) Mediterranean coppice. Ecol. Eng. 2016, 92, 82-89. [CrossRef]

44. Shapiro, S.S.; Wilk, M.B. An analysis of variance test for normality (complete samples). Biometrika 1965, 52, 591-611. [CrossRef]

45. Glass, G. V Testing homogeneity of variances. Am. Educ. Res. J. 1966, 3, 187-190. [CrossRef]

46. Pfanzagl, J.; Sheynin, O. Studies in the history of probability and statistics XLIV A forerunner of the t-distribution. Biometrika 1996, 83, 891-898. [CrossRef]

47. Fisher, R.A. The Correlation Between Relatives on the Supposition of Mendelian Inheritance. Philos. Trans. R. Soc. Edinb. 1918, 52, 399-433. [CrossRef]

48. Tukey, J.W. Comparing individual means in the analysis of variance. Biometrics 1949, 5, 99-114. [CrossRef]

49. Kruskal, W.H.; Wallis, W.A. Use of Ranks in One-Criterion Variance Analysis. J. Am. Stat. Assoc. 1952, 47, 583-621. [CrossRef]

50. Duncan, D.B. Multiple range and multiple F tests. Biometrics 1955, 11, 1-42. [CrossRef]

51. Pearson, K. LIII. On lines and planes of closest fit to systems of points in space. Lond. Edinburgh Dublin Philos. Mag. J. Sci. 1901, 2, 559-572. [CrossRef]

52. StatSoft, Inc. STATISTICA (Data Analysis Software System), Version 7.0. 2007. Available online: www.statsoft.com (accessed on 25 January 2022).

53. Hammer, Ø.; Harper, D.A.T.; Ryan, P.D. PAST: Paleontological statistics software package for education and data analysis. Palaeontol. Electron. 2001, 4, 9.

54. Spinelli, R.; Magagnotti, N.; Nati, C. Benchmarking the impact of traditional small-scale logging systems used in Mediterranean forestry. For. Ecol. Manag. 2010, 260, 1997-2001. [CrossRef]

55. Jourgholami, M.; Majnounian, B.; Abari, M.E. Effects of tree-length timber skidding on soil compaction in the skid trail in Hyrcanian forests. For. Syst. 2014, 23, 288-293. [CrossRef]

56. Picchio, R.; Magagnotti, N.; Sirna, A.; Spinelli, R. Improved winching technique to reduce logging damage. Ecol. Eng. 2012, 47, 83-86. [CrossRef]

57. Hawks, B.S.; Aust, W.M.; Bolding, M.C.; Barrett, S.M.; Schilling, E.; Fielding, J.A.H. Linkages between Forestry Best Management Practices and erosion in the southeastern U.S. J. Environ. Manag. 2022, 305, 114411. [CrossRef] 
58. Phelps, K.; Hiesl, P.; Hagan, D.; Hotaling Hagan, A. The Harvest Operability Index (HOI): A Decision Support Tool for Mechanized Timber Harvesting in Mountainous Terrain. Forests 2021, 12, 1307. [CrossRef]

59. Walsh, P.; Jakeman, A.; Thompson, C. The effects of selective timber harvesting in buffer strips along headwater channels using best management practices on runoff, turbidity and suspended sediment yield in an intensively cut eucalypt forest in southeastern Australia. For. Ecol. Manag. 2020, 458, 117812. [CrossRef]

60. Jourgholami, M.; Feghhi, J.; Tavankar, F.; Latterini, F.; Venanzi, R.; Picchio, R. Short-term effects in canopy gap area on the recovery of compacted soil caused by forest harvesting in old-growth Oriental beech (Fagus orientalis Lipsky) stands. iForest Biogeosci. For. 2021, 14, 370-377. [CrossRef]

61. Amolikondori, A.; Abrari Vajari, K.; Feizian, M.; Di Iorio, A. Influences of forest gaps on soil physico-chemical and biological properties in an oriental beech (Fagus orientalis L.) stand of Hyrcanian forest, north of Iran. iForest 2020, 13, 124-129. [CrossRef]

62. Venanzi, R.; Picchio, R.; Spinelli, R.; Grigolato, S. Soil Disturbance and Recovery after Coppicing a Mediterranean Oak Stand: The Effects of Silviculture and Technology. Sustainability 2020, 12, 4074. [CrossRef]

63. Nazari, M.; Eteghadipour, M.; Zarebanadkouki, M.; Ghorbani, M.; Dippold, M.A.; Bilyera, N.; Zamanian, K. Impacts of Logging-Associated Compaction on Forest Soils: A Meta-Analysis. Front. For. Glob. Chang. 2021, 4, 780074. [CrossRef]

64. Jaafari, A.; Najafi, A.; Zenner, E.K. Ground-based skidder traffic changes chemical soil properties in a mountainous Oriental beech (Fagus orientalis Lipsky) forest in Iran. J. Terramech. 2014, 55, 39-46. [CrossRef]

65. Wise, D.H.; Schaefer, M. Decomposition of leaf litter in a mull beech forest: Comparison between canopy and herbaceous species. Pedobiologia 1994, 38, 269-288.

66. Sariyildiz, T. Effects of gap-size classes on long-term litter decomposition rates of beech, oak and chestnut species at high elevations in northeast Turkey. Ecosystems 2008, 11, 841-853. [CrossRef]

67. Cambi, M.; Grigolato, S.; Neri, F.; Picchio, R.; Marchi, E. Effects of forwarder operation on soil physical characteristics: A case study in the Italian alps. Croat. J. For. Eng. 2016, 37, 233-239.

68. Schwegman, K.; Spinelli, R.; Magagnotti, N.; Ramantswana, M.; McEwan, A. Selecting successful harvester operators through aptitude tests and demographics. Aust. For. 2021, 84, 25-32. [CrossRef]

69. Thiffault, N.; Raymond, P.; Lussier, J.-M.; Aubin, I.; Royer-Tardif, S.; D’Amato, A.W.; Doyon, F.; Lafleur, B.; Perron, M.; Bousquet, J. Adaptive Silviculture for Climate Change: From Concepts to Reality Report on a symposium held at Carrefour Forêts 2019. For. Chron. 2021, 97, 13-27. [CrossRef] 